responded to bed rest, diuretics, and reduced food intake. Unexpected death in malnourished children during refeeding has been reported many times. ${ }^{14-16}$

This work was supported by a grant from the Wellcome Trust.

\author{
References \\ 1 Patrick, J, Xth International Congress of Nutrition, Kyoto, Japan, 1975, \\ Abstract 3115. \\ 2 Patrick, J, and Golden, M N, American fournal of Clinical Nutrition. In \\ press. \\ 3 Patrick, J, and Hilton, P J, Clinical Science, 1973, 44, 457. \\ ${ }^{4}$ Hilton, P J, and Patrick, J, Clinical Science, 1973, 44, 439.
}

5 Wellcome Classification, Lancet, 1973, 2, 87.

6 Wharton, B A, Howells, G R, and MacCance, R A, Lancet, 1967, 2, 384.

- Alleyne, G A O, Clinical Science, 1966, 30, 553.

${ }^{8}$ Alleyne, G A O, Pediatrics, 1967, 39, 400.

9 Klahr, S, and Alleyne, G A O, Kidney International, 1975, 3, 129.

${ }^{10}$ Garay, R P, and Garahan, P J, Fournal of Physiology, 1975, 249, 51.

1 Yoshida, $T$, et al, Nature, 1967, 214, 525.

12 Berkman, J M, Weir, J F, and Kepler, E J, Gastroenterology, 1947, 35, 357.

${ }^{13}$ Simonson, E, Henschel, A, and Keys, A, American Heart fournal, 1948, 35, 584 .

14 Viteri, F, et al, in Mammalian Protein Metabolism, ed H N Munro and J B Allison, vol II, p 540. New York, Academic Press, 1964.

15 Smith, R, MD Thesis, Cambridge, 1960.

16 Smythe, P M, Swanepoel, A, and Campbell, J A H, British Medical fournal, 1962, 1, 67.

(Accepted 11 February 1977)

\title{
"Methicillin-resistant" Staphylococcus aureus: reassessment by controlled trial in burns unit
}

\author{
E J L LOWBURY, H A LILLY, A KIDSON
}

British Medical fournal, 1977, 1, 1054-1056

\section{Summary}

A controlled trial of oral flucloxacillin $(250 \mathrm{mg}$ six-hourly for four days) was performed in 34 patients treated by the covered method whose burns had yielded a heavy or moderate growth of Staphylococcus aureus resistant to methicillin at $30^{\circ} \mathrm{C}$ but moderately sensitive at $37^{\circ} \mathrm{C}$. Staph aureus was eliminated in nine of the 17 patients treated with flucloxacillin but in none of the 17 controls; the proportion of patients from whose burns sensitive Staph aureus was eliminated in an earlier trial of cloxacillin was greater than this. Strains of Staph aureus commonly described as methicillin-resistant and showing heterogeneous growth at $37^{\circ} \mathrm{C}$ of many sensitive and very few resistant bacterial cells should, in the light of these findings, be called moderately sensitive to flucloxacillin. Such "heteroresistant" strains showed consistent moderate sensitivity in replicate diffusion sensitivity tests at $37^{\circ} \mathrm{C}$, but very inconsistent results in replicate dilution tests, especially with flucloxacillin. These studies showed that 18-hour diffusion sensitivity tests indicate the clinical value of treatment with flucloxacillin for staphylococcal infections of moderate severity more correctly at $37^{\circ} \mathrm{C}$ than at $30^{\circ} \mathrm{C}$.

\section{Introduction}

Cultures of Staphylococcus aureus are usually tested for sensitivity to methicillin at $30^{\circ} \mathrm{C}$, because many strains that appear sensitive at $37^{\circ} \mathrm{C}$ are found to be resistant at $30^{\circ} \mathrm{C}$. The resistant cultures include a usually very large proportion of bacterial cells that are sensitive to methicillin at $37^{\circ} \mathrm{C}$ but resistant at $30^{\circ} \mathrm{C} .^{1-6}$

MRC Industrial Injuries and Burns Unit, Birmingham Accident Hospital, Birmingham B15 1NA

E J L LOWBURY, DM, FRCPATH, bacteriologist

H A LILLY, FIMLS, chief research officer

A KIDSON, FIMLS, chief medical laboratory scientist
As the site of infection is usually at or above the normal body temperature, the use of a test at a lower temperature $(30 \mathrm{C})$ is anomalous. Moreover, many "heteroresistant" strains of Staph aureus, which appear sensitive to methicillin when tested at $37^{\circ} \mathrm{C}$ but resistant when tested at $30^{\circ} \mathrm{C}$, seem, on diffusion tests, to be sensitive or relatively sensitive to cloxacillin and flucloxacillin at both $30^{\circ} \mathrm{C}$ and $37^{\circ} \mathrm{C}$. The irregularity of results on testing such strains for sensitivity to cloxacillin has led to the further anomaly of using methicillin as the sensitivity test agent when cloxacillin or flucloxacillin are the antibiotics used for treatment. ${ }^{\circ}$

Increasing proportions of Staph aureus isolated from burns in our unit $(57 \%$ in 1972) have been found to be resistant to methicillin when tested by a ditch plate diffusion test at $30^{\circ} \mathrm{C}$.? Controlled trials soon after the introduction of methicillin and cloxacillin showed that in about $80^{\circ}$ of patients sensitive strains of Staph aureus were eliminated from burn sites covered with dressings after a course of subcutaneous methicillin ${ }^{8}$ or five days' oral treatment with cloxacillin. ${ }^{9}$ To assess the clinical sensitivity or resistance of strains of Staph aureus described as methicillin-resistant by standard tests at $30^{\circ} \mathrm{C}$, we performed a controlled trial of oral flucloxacillin in patients whose burns were colonised by such staphylococci and were covered with dressings.

\section{Method}

The burns of patients in the burns unit were routinely examined ${ }^{10}$ for bacterial flora at every change of dressing. Strains of Staph aureus picked from horse blood agar plates and identified by a tube coagulase test were examined by a ditch plate test for their sensitivity to methicillin at $30^{\circ} \mathrm{C}$ and $37^{\circ} \mathrm{C}$, with $25 \mu \mathrm{g}$ of the antibiotic per ml of nutrient agar in the ditch. A few strains were also tested by a tube dilution method with methicillin and flucloxacillin at $30^{\circ} \mathrm{C}$ and $37^{\circ} \mathrm{C} ; 0.02 \mathrm{ml}$ of a 1/250 dilution of an overnight broth culture was used as the inoculum. They were also tested by a disc diffusion test, using Mast discs of methicillin $(10 \mu \mathrm{g})$ and flucloxacillin $(5 \mu \mathrm{g})$ at $30^{\circ} \mathrm{C}$ and at $37^{\circ} \mathrm{C}$ and a 1/250 dilution of an overnight broth culture as the plate inoculum. The tests were read after 18 hours' incubation; tests at $37^{\circ} \mathrm{C}$ were reincubated at $37^{\circ} \mathrm{C}$ and read again after 42 hours. The medium used for the tests was horse blood agar.

None of the patients studied had signs of clinical infection. Their burns were treated with dressings and were found to be heavily or moderately colonised with Staph aureus that was resistant to methicillin at $30^{\circ} \mathrm{C}$, as shown by growth across the ditch, and of reduced or 
moderate sensitivity at $37^{\circ} \mathrm{C}$, as shown by a zone of inhibition smaller than that of fully sensitive strains. If eligible on clinical grounds, they were allocated alternately to treatment groups in which they received either (a) four days' course of oral flucloxacillin $(250 \mathrm{mg}$ six-hourly by mouth in adults) or (b) no specific antimicrobial treatment (controls). Only covered burns were included in the trial, because in earlier trials ${ }^{x}{ }^{9}$ burns treated by exposure showed less effective clearance of Staph aureus in response to a course of cloxacillin or methicillin than those that were covered with dressings. Any patients in the control group who, on clinical grounds, needed chemotherapy and those in the flucloxacillin treatment group who needed a different antibiotic were taken out of the trial and given the appropriate treatment.

\section{Results and comment}

Altogether 5302 isolates of Staph aureus from burns were tested by the ditch plate method, and 2476 were found to be moderately sensitive at $37 \mathrm{C}$ but resistant at $30^{\circ} \mathrm{C}$ (heteroresistant strains); no strains were resistant at both $30 \mathrm{C}$ and $37^{\circ} \mathrm{C}$. With methicillin, disc sensitivity tests (four replicates) on each of the two heteroresistant strains showed zones of inhibition in the range $3.5-4.8 \mathrm{~mm}$ at $37 \mathrm{C}$ and no inhibition at $30 \mathrm{C}$. With flucloxacillin, zones of inhibition were in the range $6 \cdot 3-8.0 \mathrm{~mm}$ at $37 \mathrm{C}$ and $4 \cdot 8-7.3 \mathrm{~mm}$ at $30 \mathrm{C}$. Tube dilution tests with methicillin and cloxacillin at $30 \% \mathrm{C}$ showed these strains to be resistant to both antibiotics at $30 \mathrm{C}$ (minimum inhibitory concentrations (MICs) were mainly $64-256 \mathrm{mg} / \mathrm{l}$ for methicillin and $64 \mathrm{mg} / \mathrm{l}$ for flucloxacillin, though some individual tests showed very low MICs). Because of such variability and because the resistance shown in most of the tube dilution tests reflects the character of a sinall proportion of the bacteria at $37 \mathrm{C}$, this method seems to be less satisfactory and to have less relevance to clinical sensitivity than disc or ditch diffusion tests, which agree with the results of treatment (see below) in showing the heteroresistant strains to be moderately sensitive to flucloxacillin. The basic resistance-that is, concentration of the antibiotic tolerated by $20 \%$ of the cells-as used by Benner and Kayser," avoids this difficulty but could not be used as a routine test.

The table shows the results of the controlled trial of flucloxacillin for Staph aureus moderately sensitive at $37 \mathrm{C}$ and resistant at $30 \mathrm{C}$. In the 17 patients treated with flucloxacillin 10 out of 21 burn sites were cleared of Staph aureus, while none of the 18 burns in the controls were cleared of Staph aureus $\left(\gamma^{2}=9 \cdot 16 ; P<0 \cdot 01\right)$. Nine of the 17 patients treated with flucloxacillin and none of the 17 controls lost their staphylococci $\left(\%^{2}=9 \cdot 67 ; \mathrm{P}<0.01\right)$.

Results in controlled trial of flucloxacillin in patients whose burns zere colonised by methicillin-resistant Staph aureus compared with those of an earlier trial of cloxacillin for methicillin-sensitive infections ${ }^{9}$

\begin{tabular}{|c|c|c|c|c|c|}
\hline & \multirow{2}{*}{$\begin{array}{l}\text { No of } \\
\text { patients }\end{array}$} & \multirow{2}{*}{$\begin{array}{l}\text { No of } \\
\text { burns }\end{array}$} & \multicolumn{3}{|c|}{$\begin{array}{c}\text { No of covered burns from which } \\
\text { Staph aureus was: }\end{array}$} \\
\hline & & & Eliminated & Reduced & $\begin{array}{l}\text { Eliminated } \\
\text { or reduced }\end{array}$ \\
\hline $\begin{array}{l}\text { Flucloxacillin: } \\
\text { Treated group } \ldots \\
\text { Control group } \ldots \\
\text { Cloxacillin": }\end{array}$ & $\begin{array}{l}17 \\
17\end{array}$ & $\begin{array}{l}21 \\
18\end{array}$ & $10(48 \% *$ & $\begin{array}{l}3 \\
3\end{array}$ & $\begin{aligned} 13 & (62 \%) \ddagger \\
3 & (17 \%) \ddagger\end{aligned}$ \\
\hline $\begin{array}{l}\text { Treated group } \ldots \\
\text { Control group } \ldots\end{array}$ & $\begin{array}{l}14 \\
16\end{array}$ & $\begin{array}{l}17 \\
17\end{array}$ & $\begin{aligned} 14(82 \%)^{+} \\
3(18 \%)^{+}\end{aligned}$ & $\begin{array}{l}3 \\
2\end{array}$ & $\begin{array}{l}17(100 \%) \S \\
5(29 \%) \S\end{array}$ \\
\hline
\end{tabular}
$* y^{2}=9.16 ; \quad P<0.01 . \quad+\%^{2}=11.76 ; \quad P<0.001 . \quad+\%^{2}=6.44 ; \quad P<0.02 . \$ \%^{2}=15.58$
$P<0.001$.

The results of a similar" trial of cloxacillin $(500 \mathrm{mg}$ six-hourly for five days) in patients with Staph aureus in covered burns, which was carried out when the antibiotic was new, are also shown in the table; all strains were found to be sensitive, and a larger proportion of burns $\left(82^{\circ}\right.$ ) was cleared of Staph aureus than in this trial. Nevertheless, the difference between the results of these trials is possibly less than the percentage clearance from antibiotic-treated cases would suggest, because three of the 17 burns in the control patients of the earlier trial lost their staphylococci, whereas none of the burns of the controls were cleared in this trial. Results similar to those in the cloxacillin trial were obtained in an earlier controlled trial of methicillin given by intramuscular injection, in which 32 out of $40(80 \%)$ covered burns were cleared of Staph aureus. "

Comparability of groups in trial-The 10 males and seven females treated with flucloxacillin had a mean estimated area of burn of
$16.5 \%$ (range $0 \cdot 7-41.5 \%$ ) and a mean age of $27 \cdot 1$ years (range 5 months59 years). The corresponding means for the seven male and 10 female controls were $15.5 \%$ (range $0.5-42 \%$ ) and 42.9 years (range 8 months85 years).

\section{Discussion}

The incidence of methicillin-resistant Staph aureus increased during and after the 1960 s, reaching proportions as high as $40-50^{\circ}{ }_{0}$ of the strains isolated in some hospitals. ${ }^{71-13}$ The potential clinical importance of such strains has been established, but there has been little evidence to show that methicillin and its analogues are ineffective in treating human infections caused by these strains, although the term "methicillinresistant" (and, by implication, also "cloxacillin- and flucloxacillin-resistant") would suggest this. Discouraging results have been reported in treating experimental infections with such strains in animals, ${ }^{1+15}$ and opinions vary on the potential response to treatment of human infections with such strains. ${ }^{11}{ }^{16}$ It is well known that staphylococci described as resistant on the basis of tests at $30 \mathrm{C}$ with methicillin was generally found to be sensitive to methicillin (at least by diffusion tests) and even more sensitive to cloxacillin and flucloxacillin when the tests are done at $37 \mathrm{C}$ and read after 18 hours' incubation. At $37^{\circ} \mathrm{C}$ there are usually very few resistant cells in a predominantly sensitive culture. Cloxacillin or flucloxacillin, rather than methicillin, however, are the antibiotics in this group most often used for treatment, and the temperature of the infected lesion is likely to be about $37^{\circ} \mathrm{C}$ or above. Therefore tests with these antibiotics at $37 \mathrm{C}$, when consistent, must give a closer indication of their probable therapeutic value (except, probably, in septicaemia and other very severe infections) than the standard methicillin sensitivity tests at $30^{\circ} \mathrm{C}$.

This view is supported by the results of our controlled trial of flucloxacillin. The clearance of methicillin-resistant Staph aureus from 10 out of 21 burns (in nine out of 17 patients) after four days' treatment with flucloxacillin, while no such organisms were cleared from any of the 18 burns in the 17 control patients, suggests that these strains should be called "moderately sensitive to flucloxacillin" rather than "methicillin-resistant." The results were apparently not quite as good as those found in our earlier trials of methicillin and cloxacillin against methicillinsensitive strains. But this difference is consistent with the difference in results of in-vitro diffusion sensitivity tests at $37^{\circ} \mathrm{C}$ on methicillin-sensitive and methicillin-resistant strains, in which the latter were shown to be sensitive but usually less so than the former.

The tube dilution method showed large discrepancies between replicate tests with flucloxacillin carried out on different occasions, presumably because different inocula had contained different proportions of flucloxacillin-sensitive and flucloxacillin-resistant bacteria. There was more consistency in tube dilution tests on such strains with methicillin, though MICs of methicillin were misleading in relation to flucloxacillin treatment, as they showed the strains to be resistant. There was diminished growth on two or more doubling dilutions beyond the MIC in most of the tube dilution tests. Dilution tests are generally regarded as giving the most useful in-vitro evidence of probable clinical sensitivity or resistance of an infecting organism, but this does not apply in the case of flucloxacillin, either at $30^{\circ} \mathrm{C}$ or at $37^{\circ} \mathrm{C}$, in which the resistance indicates the character of a (usually) very small proportion of the bacteria present. Diffusion tests, on the other hand, provide consistent results, by which the heteroresistant strains are shown to be moderately sensitive, as they are in their response to systemic treatment with flucloxacillin. Though the resistant component of heteroresistant cultures may grow in the presence of flucloxacillin at concentrations that exceed the usual peak blood concentration, they grow more slowly in the presence of methicillin and its analogues than the sensitive bacteria, ${ }^{17}$ and they are likely to be at a disadvantage in competition with more vigorous 
organisms colonising the wound and also, perhaps, with the natural defences.

Clinical sensitivity tests are required to give information on the possible effectiveness of treatment with an antibiotic, and for this purpose 18-hour diffusion tests with flucloxacillin at $37^{\circ} \mathrm{C}$ might be adequate. These would also detect the emergence of strains of Staph aureus highly resistant to flucloxacillin at $37^{\circ} \mathrm{C}$-a type of resistance which we have not yet encountered but for which the microbiologist must be vigilant. Benner and Kayser" ${ }^{11}$ found an increasing proportion of clinical isolates of Staph aureus in which most cells in the culture were resistant to methicillin and its analogues, and infection with such strains was less responsive to treatment with these antibiotics. The heteroresistant state is best shown by parallel sensitivity tests with methicillin at $30^{\circ} \mathrm{C}$ and at $37^{\circ} \mathrm{C}$, or by 18 - and 42 -hour methicillin sensitivity tests at $37^{\circ} \mathrm{C}$, which would also show the reduced sensitivity of these strains at $37^{\circ} \mathrm{C}$ and detect the emergence of a strain highly resistant at $37^{\circ} \mathrm{C}$. Methicillin sensitivity tests done only at $30^{\circ} \mathrm{C}$ would fail to detect the emergence of such highly resistant strains, as well as failing to recognise the potential value of flucloxacillin and its analogues in treatment of infections by heteroresistant strains of Staph aureus.
We thank Mr D M Jackson and the staff of the burns unit for their co-operation.

\section{References}

${ }^{1}$ Annear, D I, Medical fournal of Australia, 1968, 1, 444.

2 Dyke, K G H, fournal of Medical Microbiology, 1969, 2, 261.

3 Rolinson, G N, British Medical fournal, 1961, 1, 125.

- Knox, R, British Medical fournal, 1961, 1, 126.

5 Chabbert, Y A, et al, Revue Française d'Etudes Cliniques et Biologiques, 1965, $10,495$.

${ }^{6}$ Hewitt, J H, Coe, A W, and Parker, M T, fournal of Medical Microbiology, $1969,2,443$.

7 Ayliffe, G A J, et al, fournal of Clinical Pathology, 1977, 30, 40.

${ }^{8}$ Lowbury, E J L, et al, Lancet, 1961, 1, 1318.

${ }^{9}$ Lowbury, E J L, and Miller, R W S, Lancet, 1962, 2, 640.

10 Lowbury, E J L, British Medical fournal, 1960, 1, 994.

1 Benner, E J, and Kayser, F H, Lancet, 1968, 2, 741.

12 Parker, M T, and Hewitt, J H, Lancet 1970, 1, 800.

13 Siboni, K, and Poulsen, E D, Danish Medical Bulletin, 1968, 15, 161.

${ }^{14}$ Bulger, R J, Feigl, P, and Nielson, K, Fournal of Infectious Diseases, 1972, $126,674$.

${ }^{15}$ Ayliffe, G A J, Andrews, J, and Williams, J D, Lancet, 1974, 1, 573.

${ }^{16}$ Lacey, R W, Fournal of Clinical Pathology, 1973, 26, 899.

17 Sutherland, R, and Rolinson, G N, fournal of Bacteriology, 1964, 87, 887.

(Accepted 22 February 1977)

\title{
A small cluster of Hodgkin's disease
}

\author{
A R EVANS, B W HANCOCK, M J BROWN, J RICHMOND
}

British Medical fournal, 1977, 1, 1056-1057

\section{Summary}

Nine cases of Hodgkin's disease and one of acute lymphoblastic leukaemia occurred in 1972-5 in an area of less than $1 \mathrm{~km}^{2}$. Clinical, social, and drug histories provided no relevant information, and definite patient-to-patient contacts before the onset of disease were not established. There was a higher incidence of malignant neoplasms in first-degree relatives of the patients than in those of a small control group living in the same area. There was no apparent reason for this cluster of cases, but geographical, climatic, and entomological studies are being carried out.

\section{Introduction}

Reports of cases of Hodgkin's disease ${ }^{1-4}$ and leukaemia ${ }^{5-7}$ occurring in a pattern similar to that seen in infectious disease have stimulated interest in space-time clustering in all types of

Sheffield Area Health Authority

A R EVANS, DOBSTRCOG, MRCGP, general practitioner

Department of Haematology, Northern General Hospital, Sheffield S5 7AU

M J BROWN, MB, MRCPATH, consultant haematologist

University Department of Medicine, Royal Hospital, Sheffield S1 3SR B W HANCOCK, DCH, MRCP, lecturer

J RICHMOND, MD, FRCP, professor lymphoreticular and haematological malignancies. We recently heard about a cluster of five patients with Hodgkin's disease living close to each other, and further investigation disclosed a further four cases of Hodgkin's disease and one of leukaemia within an area of less than $1 \mathrm{~km}^{2}$ (population about 2800). All these patients presented within a period of four years. We describe here the clinical and epidemiological findings.

\section{Patients and methods}

Full clinical and histological details were available for all 10 patients. All were interviewed and epidemiological inquiries made. The immune status of four patients was assessed by in-vivo and in-vitro techniques.

\section{Results}

The incidence of Hodgkin's disease in the area studied was greater than 70 cases per 100000 population per year, although the expected incidence (for the Sheffield metropolitan area) was 4-5 cases per 100000 per year. The clinical and epidemiological details of the patients are summarised in the table and their homes are marked on the map. For reasons of confidentiality we have not given precise details of roadways.

The patients had no common features in their medical histories, and the incidence of glandular fever, tonsillectomy, and appendicectomy was not increased. The drug and social histories of the patients were unremarkable but the incidence of malignant neoplasms among first-degree relatives seemed to be higher than in a group of 30 patients matched for age and sex who were attending the local general practitioner's surgery. Among first-degree relatives of the controls there were seven malignant neoplasms (three gastrointestinal, two lung, one haematological, and one where the primary site was undetermined), while among those of the 10 patients studied there were six (four gastrointestinal, one lung, and one haematological).

No definite patient-to-patient contacts were elicited, despite the fact that several of the patients lived very near to one another. No 